Editorial

\title{
Preface: Special Issue on Sustainable Territorial Management
}

\author{
David Rodríguez-Rodríguez ${ }^{1,2, *(1)}$ and Javier Martínez-Vega ${ }^{1}$ \\ 1 Institute of Economy, Geography and Demography, Spanish National Research Council (IEGD-CSIC), \\ Associated Unit GEOLAB, Albasanz, 26-28, 28037 Madrid, Spain; javier.martinez@cchs.csic.es \\ 2 European Topic Centre-University of Malaga, Andalucía Tech, University of Malaga, 29010 Malaga, Spain \\ * Correspondence: david.rodriguez@csic.es; Tel.: +34-916-022-322 or +34-951-953-102
}

Received: 30 July 2018; Accepted: 2 August 2018; Published: 5 August 2018

check for updates

\section{Introduction}

Human development has made remarkable social and economic progress possible for most of us [1,2], but has also entailed a range of negative consequences on natural resources, local communities, and the economy at multiple scales. Soil sealing [3-5], erosion, land degradation and erosion [6]; air and water pollution [7,8]; forest fires [9], biodiversity homogenisation and loss [10], isolation and fragmentation of habitats [11,12], poverty [13], human migration [14] and health issues [15,16] are among the most common human-made impacts with a clear sustainability and spatial component. They occur almost everywhere in the territory, be it terrestrial [17], aerial [18] or marine [19], where there is human activity.; Thus, achieving sustainable territorial management that combines healthy and prosperous societies with the long-term maintenance of biodiversity and productive ecosystem services [20] remains the biggest challenge of our modern world [21]. Simulation models of future land uses, under different scenarios of change, can help territorial managers in the decision-making process [22].

This Special Issue seeks to collect a coherent set of studies on techniques and experiences (case studies) aimed at increasing the environmental, social, economic \&/or institutional sustainability of landscapes and seascapes from a range of geographic and socioeconomic contexts.

\section{Highlights}

Land use-land cover (LULC) changes towards intensive uses, especially towards artificial uses, are one of the main global threats to biodiversity conservation. Thus, LULC changes are considered a cornerstone in sustainable territorial management (Figure 1), so a number of articles in this Special Issue deal with this topic directly or indirectly. Geographically, ten case studies representing urban areas, rural areas (chiefly protected areas; PAs) and coastal areas from four countries in Europe and Asia are shown. 


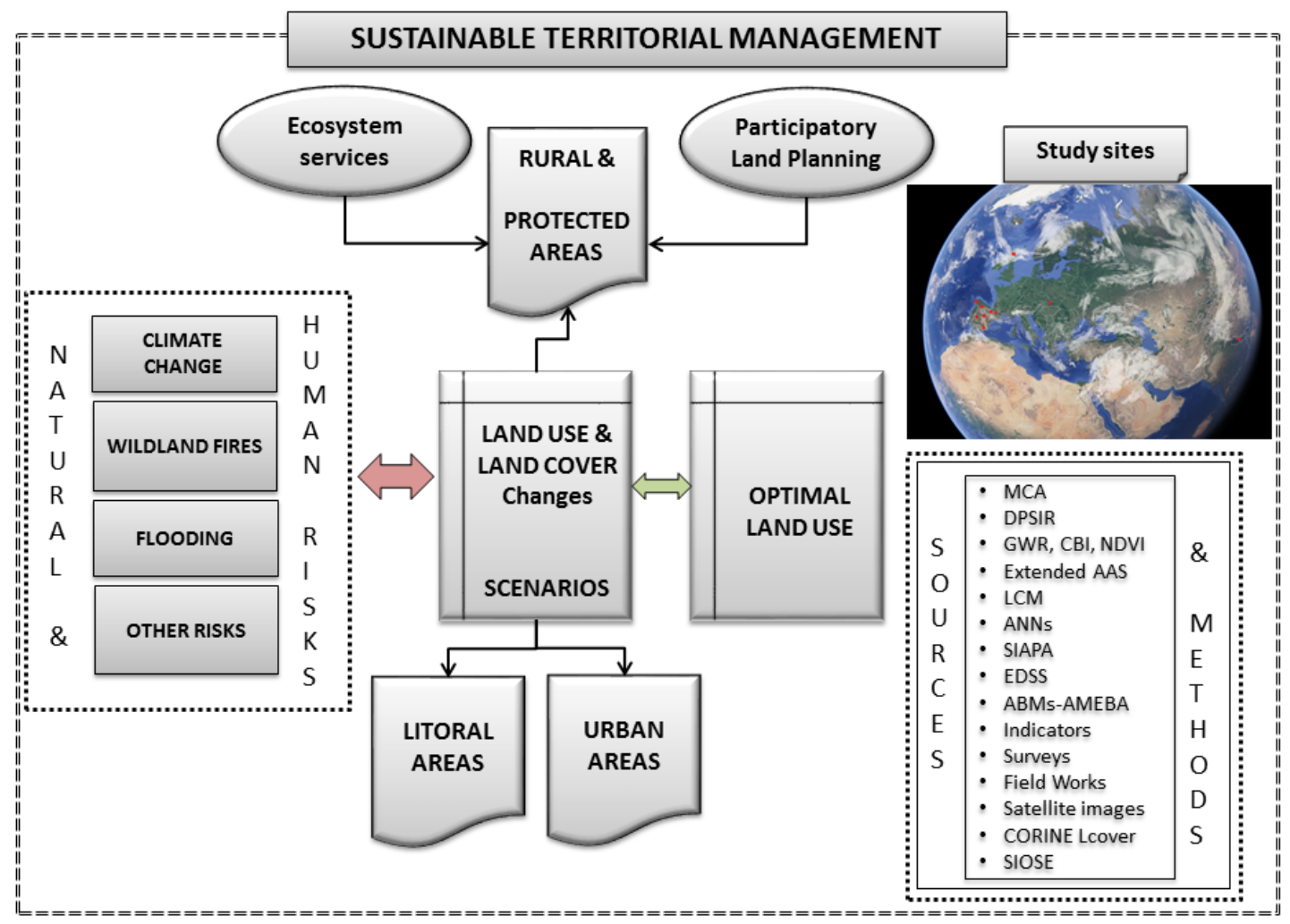

Figure 1. Simplified conceptual framework of ten papers compiled in this Special Issue (picture from Google Earth). MCA: Multi-Criteria Analysis; DPSIR: Driving force-Pressure-State-Impact-Response; GWR: Geographically Weighted Regression; CBI: Composite Burn Index; NDVI: Normalized Difference Vegetation Index; AAS: Agroforestry Accounting System; LCM: Land Change Modeller; ANNs: Artifical Neural Networks; SIAPA: System for the Integrated Assessment of Protected Areas; EDSS: Environmental Decision Support System; ABMs-AMEBA: Agent-Based Models; CORINE Lcover: CORINE Land Cover; SIOSE: Geographic Information System on Land Use-Land Cover of Spain.

Izakovičová et al., 2018 [23] use an integrated approach to attain sustainable LULC management in an agricultural area of western Slovakia. They analyse drivers of LULC change and their impacts on the environment. They propose optimal land uses accounting for interactions among available natural capital, environmental conditions and human needs in the long term to achieve socioeconomic development. They use multi-criteria analysis to guide managers' decision-making.

Forest fires also hamper sustainable territorial management and cause substantial environmental and socioeconomic losses. Viana-Soto et al., 2017 [24] assess regeneration of vegetation in burned areas of the Mediterranean region (Iberian Peninsula). They seek to understand species' recovery dynamics in order to implement suitable restoration actions. Regeneration modelling has been performed through multiple regressions, using ordinary least squares and geographic weight regression. They measure the severity of fire through the composite burn index and a set of environmental variables. They estimate the dynamics of regeneration through the Normalized Difference Vegetation Index obtained from Landsat images.

Furthermore, flooding is a persistent problem in coastal areas. Under scenarios of climate change, it is expected that flooding events will become more frequent and potentially more intense. This risk represents a potential threat to coastal communities that depend on coastal resources to a large extent. Toubes et al., 2017 [25] develop a methodology for coastal flooding risk assessment based on an index that compares 16 hydro-geo-morphological, biophysical, human exposure and resilience indicators, with a specific focus on tourism. They assess the vulnerability to floods of 724 beaches in Galicia (northern Spain). Their results are useful for coastal adaptation and management. 
Knowing the value of the services provided by different ecosystems is essential for sustainable territorial management. Nevertheless, the Standard Economic Accounts for Agriculture and Forestry do not measure the ecosystem services and intermediate products embedded in the final products and ignore the private non-commercial intermediate products and self-consumption of private amenities. Campos et al., 2017 [26] apply the Agroforestry Accounting System to simulate sustainable forestry of holm oak and cork oak in Dehesa de la Luz, a Mediterranean tree-grass ecosystem. The net value added is more than 2.3 times greater than the estimated net value using the standard accounts.

Hewitt \& Macleod, 2017 [27] use an Environmental Decision Support System (EDSS) to support the management of land and freshwater resources in Scotland, UK, with multiple applications to environmental management. They design a structured participatory process to determine stakeholder requirements, establish principles to meet these requirements and test the prototypes. The resulting specification of this bottom-up process is a free EDSS that is spatially explicit and compatible with portable devices. This application, still under development, does not resemble most existing EDSSs. Its focus on adaptive, stakeholder-centred environmental management strategies based on outcomes offers an opportunity to make better use of these new technologies to aid decision-making processes.

The rapid growth of urban areas close to large metropolises causes negative impacts on natural resources. This Special Issue includes two case studies focused on LULC changes in urban areas. In the first one, Ishtiaque et al., 2017 [28] analyse the increasing urbanization of the Kathmandu Valley (Nepal), in the foothills of the Himalayas. They use four Landsat images of the years 1989, 1999, 2009 and 2016 to compare changes. They relate LULC changes with a set of immediate causes and driving-factors of those changes. They employ a pixel-based hybrid classification approach and analyse the LULC trajectories. The results show that the urban area expanded to $412 \%$ in the last three decades.

Cantergiani \& Gómez Delgado, 2018 [29] develop AMEBA, a prototype of an exploratory, spatial, agent-based model that considers the main stakeholders involved in the urban development process (urban planners, developers and the population). It consists of three sub-models, one for each agent. The first two are based on a land use allocation technique and the last one, as well as their integration, on an agent-based model approach. The authors describe the conceptualisation and performance of the sub-models that represent urban planners and developers, who are the agents responsible for officially expanding urban land and defining its spatial allocation. The prototype is tested in Corredor del Henares (an urban-industrial area in the Region of Madrid, central Spain), but it is flexible to be adapted to other study areas under different urban growth contexts.

PAs are also affected by LULC changes and other pressures from global change. Some processes such as intensive recreational use, forest fires or the expansion of artificial areas inside and around them jeopardise their environmental sustainability and effectiveness. Martínez-Vega et al., 2017 [30] analyse the LULC changes that took place between 1990 and 2006 in two Spanish national parks (NPs). They also simulate LULC changes between 2006 and 2030 through Artificial Neural Networks, taking into account a business-as-usual scenario and a green scenario. The simulation of LULC changes that are expected in the following decades under different scenarios is a strategic issue to carry out preventive protected area planning and management. Finally, they perform a multi-temporal analysis of natural habitat fragmentation in each NP.

López \& Pardo 2018 [31] design an indicator system to monitor and assess the socioeconomic impacts of climate change on Sierra de Guadarrama NP (Spain) that could be used in other PAs in Spain and elsewhere. Indicators assess natural resource use, population change, economic activities and socio-political interactions. They use statistical sources and surveys according to the Driving forces-Pressure-State-Impact-Response framework.

As global biodiversity trends worsen, PA environmental effectiveness evaluation becomes an urgent need to identify strengths and areas to improve. Through a participatory process including PA managers and scientists, Rodríguez-Rodríguez et al., 2017 [32] refine the System for the Integrated Assessment of Protected Areas (SIAPA) in order to increase its legitimacy, credibility and salience to 
end users in Spain. Then, they test the optimised version of the SIAPA on two emblematic Spanish NPs: Ordesa y Monte Perdido NP, and Sierra de Guadarrama NP. Results show that potential environmental effectiveness is moderate for Ordesa NP and low for Guadarrama NP, according to the indicators that could be evaluated. PA managers and scientists largely coincided in the ratings of SIAPA's indicators and indices.

We hope that the methods developed, the results obtained, and the discussions included in the above-mentioned papers are useful to understand the potential of data modelling techniques, support future research, raise awareness about the complex problems of the territory and provide robust knowledge upon which to base sustainable territorial management.

Conflicts of Interest: The authors declare no conflict of interest.

\section{References}

1. Huang, L.; Yan, L.; Wu, J. Assessing urban sustainability of Chinese megacities: 35 years after the economic reform and open-door policy. Landsc. Urban Plan. 2016, 145, 57-70. [CrossRef]

2. García-Ayllón, S. Rapid development as a factor of imbalance in urban growth of cities in Latin America: A perspective based on territorial indicators. Habitat Int. 2016, 58, 127-142. [CrossRef]

3. Pons, A.; Rullán, O. Artificialization and Islandness on the Spanish Tourist Coast. Misc. Geogr-Reg. Stud. Dev. 2014, 18, 5-16. [CrossRef]

4. De Andrés, M.; Barragán, J.M.; García Sanabria, J. Relationships between coastal urbanization and ecosystems in Spain. Cities 2017, 68, 8-17. [CrossRef]

5. Rodríguez-Rodríguez, D.; Martínez-Vega, J. Protected area effectiveness against land development in Spain. J. Environ. Manag. 2018, 215, 345-357. [CrossRef] [PubMed]

6. García-Ruiz, J.M.; Beguería, S.; Nadal-Romero, E.; González-Hidalgo, J.C.; Lana-Renault, N.; Sanjuán, Y. A meta-analysis of soil erosion rates across the world. Geomorphology 2015, 239, 160-173. [CrossRef]

7. Chen, B.; Song, Y.; Kwan, M.P.; Huang, B.; Xu, B. How do people in different places experience different levels of air pollution? Using worldwide Chinese as a lens. Environ. Pollut. 2018, 238, 874-883. [CrossRef] [PubMed]

8. Carrascal Incera, A.; Avelino, A.F.T.; Franco Solís, A. Gray water and environmental externalities: International patterns of water pollution through a structural decomposition analysis. J. Clean. Prod. 2017, 165, 1174-1187. [CrossRef]

9. Chuvieco, E. Earth Observation of Wildland Fires in Mediterranean Ecosystems; Springer-Verlag: Berlin/Heidelberg, Germany, 2009.

10. Uchida, K.; Koyanagi, T.F.; Matsumura, T.; Koyama, A. Patterns of plant diversity loss and species turnover resulting from land abandonment and intensification in semi-natural grasslands. J. Environ. Manag. 2018, 218, 622-629. [CrossRef] [PubMed]

11. Lui, G.V.; Coomes, D.A. Tropical nature reserves are losing their buffer zones, but leakage is not to blame. Environ. Res. 2016, 147, 580-589. [CrossRef] [PubMed]

12. Piqueray, J.; Bisteau, E.; Cristofoli, S.; Palm, R.; Poschlod, P.; Mahy, G. Plant species extinction debt in a temperate biodiversity hotspot: Community, species and functional traits approaches. Biol. Conserv. 2011, 144, 1619-1629. [CrossRef]

13. Fardoust, S.; Kanbur, R.; Luo, X.; Sundberg, M. An evaluation of the feedback loops in the poverty focus of world bank operations. Eval. Program Plan. 2018, 67, 10-18. [CrossRef] [PubMed]

14. Small, C.; Sousa, D.; Yetman, G.; Elvidge, C.; MacManus, K. Decades of urban growth and development on the Asian megadeltas. Glob. Planet. Chang. 2018, 165, 62-89. [CrossRef]

15. Gao, X.B.; Zhang, F.C.; Wang, C.; Wang, Y.X. Coexistence of High Fluoride Fresh and Saline Groundwaters in the Yuncheng Basin, Northern China. Procedia Earth Planet. Sci. 2013, 7, 280-283. [CrossRef]

16. Rahman, M.A.; Rahman, A.; Khan, M.Z.K.; Renzaho, A.M.N. Human health risks and socio-economic perspectives of arsenic exposure in Bangladesh: A scoping review. Ecotoxicol. Environ. Saf. 2018, 150, 335-343. [CrossRef] [PubMed]

17. Almeida, D.; Neto, C.; Esteves, L.S.; Costa, J.C. The impacts of land-use changes on the recovery of saltmarshes in Portugal. Ocean Coast. Manag. 2014, 92, 40-49. [CrossRef] 
18. Pérez-García, J.M.; DeVault, T.L.; Botella, F.; Sánchez-Zapata, J.A. Using risk prediction models and species sensitivity maps for large-scale identification of infrastructure-related wildlife protection areas: The case of bird electrocution. Biol. Conserv. 2017, 210, 334-342. [CrossRef]

19. Ward-Paige, C.A.; Worm, B. Global evaluation of shark sanctuaries. Glob. Environ. Chang. 2017, 47, $174-189$. [CrossRef]

20. Förster, J.; Barkmann, J.; Fricke, R.; Hotes, S.; Kleyer, M.; Kobbe, S.; Kübler, D.; Rumbaur, C.; Siegmund-Schultze, M.; Seppelt, R.; et al. Assessing ecosystem services for informing land-use decisions: A problem-oriented approach. Ecol. Soc. 2015, 20, 31. [CrossRef]

21. World Bank. Sustainable Land Management: Challenges, Opportunities, and Trade-Offs; Agriculture and Rural Development, World Bank: Washington, DC, USA, 2006. Available online: https:/ /www.openknowledge. worldbank.org/handle/10986/7132 (accessed on 30 July 2018).

22. Camacho Olmedo, M.T.; Paegelow, M.; Mas, J.F.; Escobar, F. Geomatic Approaches for Modeling Land Change Scenarios; Lecture Notes in Geoinformation and Cartography; Springer: Berlin, Germany, 2018.

23. Izakovičová, Z.; Špulerová, J.; Petrovič, F. Integrated Approach to Sustainable Land Use Management. Environments 2018, 5, 37. [CrossRef]

24. Viana-Soto, A.; Aguado, I.; Martínez, S. Assessment of Post-Fire Vegetation Recovery Using Fire Severity and Geographical Data in the Mediterranean Region (Spain). Environments 2017, 4, 90. [CrossRef]

25. Toubes, D.R.; Gössling, S.; Hall, C.M.; Scott, D. Vulnerability of Coastal Beach Tourism to Flooding: A Case Study of Galicia, Spain. Environments 2017, 4, 83. [CrossRef]

26. Campos, P.; Mesa, B.; Álvarez, A.; Castaño, F.M.; Pulido, F. Testing Extended Accounts in Scheduled Conservation of Open Woodlands with Permanent Livestock Grazing: Dehesa de la Luz Estate Case Study, Arroyo de la Luz, Spain. Environments 2017, 4, 82. [CrossRef]

27. Hewitt, R.J.; Macleod, C.J.A. What Do Users Really Need? Participatory Development of Decision Support Tools for Environmental Management Based on Outcomes. Environments 2017, 4, 88. [CrossRef]

28. Ishtiaque, A.; Shrestha, M.; Chhetri, N. Rapid Urban Growth in the Kathmandu Valley, Nepal: Monitoring Land Use Land Cover Dynamics of a Himalayan City with Landsat Imageries. Environments 2017, 4, 72. [CrossRef]

29. Cantergiani, C.; Gómez Delgado, M. Urban Land Allocation Model of Territorial Expansion by Urban Planners and Housing Developers. Environments 2018, 5, 5. [CrossRef]

30. Martínez-Vega, J.; Díaz, A.; Nava, J.M.; Gallardo, M.; Echavarría, P. Assessing Land Use-Cover Changes and Modelling Change Scenarios in Two Mountain Spanish National Parks. Environments 2017, 4, 79. [CrossRef]

31. López, I.; Pardo, M. Socioeconomic Indicators for the Evaluation and Monitoring of Climate Change in National Parks: An Analysis of the Sierra de Guadarrama National Park (Spain). Environments 2018, 5, 25. [CrossRef]

32. Rodríguez-Rodríguez, D.; Ibarra, P.; Martínez-Vega, J.; Echeverría, M.; Echavarría, P. Fine-Tuning of a Protected Area Effectiveness Evaluation Tool: Implementation on Two Emblematic Spanish National Parks. Environments 2017, 4, 68. [CrossRef]

(C) 2018 by the authors. Licensee MDPI, Basel, Switzerland. This article is an open access article distributed under the terms and conditions of the Creative Commons Attribution (CC BY) license (http://creativecommons.org/licenses/by/4.0/). 